\title{
CYP2A6 overexpression in human lung cancers correlates with a high malignant status
}

\author{
YOKO MATSUDA ${ }^{1}$, KEIKO YAMAKAWA ${ }^{1}$, KOUSUKE SAOO ${ }^{1}$, KYOKO HOSOKAWA ${ }^{1}$, \\ MASANAO YOKOHIRA ${ }^{1}$, TOSHIYA KUNO ${ }^{1}$, JUNKO IWAI ${ }^{2}$, TAKATOSHI SHIRAI $^{2}$, \\ KAORU OBIKA ${ }^{3}$, TETSUYA KAMATAKI ${ }^{4}$ and KATSUMI IMAIDA ${ }^{1}$ \\ ${ }^{1}$ Onco-Pathology, Department of Pathology and Host-Defense, Faculty of Medicine, Kagawa University, 1750-1 \\ Ikenobe, Miki-cho, Kita-gun; ${ }^{2}$ Pathology Laboratory, Department of Central Clinical Laboratory, and \\ ${ }^{3}$ Orthopedic Surgery, Takinomiya General Hospital, JA Kagawa Koseiren, 486 Takinomiya, \\ Ryonan-cho, Ayauta-gun, Kagawa; ${ }^{4}$ Takasaki University of Health and Welfare, \\ Faculty of Pharmacy, 60 Nakaorui-cho, Takasaki-shi, Gunma, Japan
}

Received February 2, 2007; Accepted March 12, 2007

\begin{abstract}
CYP2A6 is a major phase I enzyme metabolizing tobacco-specific nitrosamines, implicated as risk factors for lung cancer. In this study, immunohistochemistry and in situ hybridization (ISH) for CYP2A6 with human lung cancer tissues $(n=31)$ obtained by surgical resection showed significantly higher immunoreactivity in the cases with lymph node metastasis. The adenocarcinoma cases $(n=23)$ with lymph node metastasis or large tumor size showed a high immunoreactivity for CYP2A6. The squamous cell carcinoma cases $(n=6)$ with large tumor size showed a tendency for low CYP2A6 immunoreactivity. ISH for CYP2A6 revealed mRNA expression in both adenocarcinoma and squamous cell carcinoma cells. The data suggest that CYP2A6 could have an important role in the development and proliferation of lung carcinomas. With adenocarcinomas, CYP2A6 could be a target candidate for therapeutic and chemopreventive intervention.
\end{abstract}

\section{Introduction}

Lung cancer is one of the most common cancers, causing high mortality and morbidity throughout the world (1). Tobacco smoking is the most important risk factor with roles for multiple carcinogens, including 4-(methylnitrosamino)-1(3-pyridyl)-1-butanone (NNK) and polycyclic aromatic hydrocarbons (2). Cytochrome P450 (CYP) 2A6 is the major

Correspondence to: Dr Katsumi Imaida, Onco-Pathology, Department of Pathology and Host-Defense, Faculty of Medicine, Kagawa University, 1750-1 Ikenobe, Miki-cho, Kita-gun, Kagawa 761-0793, Japan

E-mail:imaida@med.kagawa-u.ac.jp

Key words: CYP2A6, lung, adenocarcinoma, squamous cell carcinoma, lymph node metastasis, immunohistochemistry phase I enzyme responsible for the metabolic activation of NNK (3-5) and epidemiological studies have shown several polymorphisms of the CYP2A6 gene to be associated with lung cancer risk (6-9) and tobacco smoking behavior (6). We have previously reported that lung adenoma induction in female A/J mice by NNK is strongly suppressed by pretreatment with 8-methoxypsoralen, a potent human CYP2A6 inhibitor $(10,11)$. Furthermore, the CYP2A protein is expressed in NNK-induced lung adenomas (12). Thus CYP2A6 inhibition has emerged as a candidate approach for the chemoprevention of lung cancer. Although CYP2A6 is known to be expressed in human bronchial mucosae and at lower levels in peripheral lung tissues $(13,14)$, only limited information is available regarding human lung cancer tissues. Therefore, the present immunohistochemical study was performed to assess the expression of the CYP2A6 protein in lung carcinomas with reference to clinicopathological features.

\section{Materials and methods}

Patients and surgical specimens. Samples of lung tissue, which were diagnosed as lung carcinoma clinically and pathologically, were obtained by surgical resection $(n=31)$. All of the excised tissues were fixed with $10 \%$ neutral formalin and embedded in paraffin. The sections $(4 \mu \mathrm{m})$ were stained with $\mathrm{H} \& \mathrm{E}$ for histopathological examination. Histologically, a total of 31 lung specimens were classified according to the WHO histological classification $(15,16)$. The samples were diagnosed as 23 cases of adenocarcinoma, 6 cases of squamous cell carcinoma (SCC), 1 case of large cell carcinoma and 1 case of small cell carcinoma. All the carcinoma cases were classified into well $(n=13)$, moderate $(n=10)$ and poor differentiation $(n=6)$. Furthermore, the adenocarcinomas were subdivided into bronchioalveolar carcinoma $(B A C, n=4)$ and invasive carcinoma $(n=19)$. In all cases, tumor size, lymph node metastasis, pleural invasion and metastasis in the lung were analyzed microscopically. The smoking behavior for each case was determined from data in the medical records. A summary of all the cases is shown in Table II. 
Table I. Sequences of the CYP2A6 primers used for probe preparation in in situ hybridization.

Primer sequences $\left(5^{\prime}-3^{\prime}\right)$

\author{
1st PCR \\ Forward (SP6 + CYP2A6) \\ Reverse (T7 + CYP2A6)
}

2nd PCR

Forward (SP6)

Reverse (T7)

\section{ATTTAGGTGACACTATAGAATGGGTCTTCAAAGGCTATGG AATACGACTCACTATAGGGCCATGCGGATGAGAAAGGAGT}

Immunohistochemical staining of CYP2A6. A total of 31 lung sections obtained from typical lesions in each case were used for immunohistochemistry. CYP2A6 immunoreactivity was identified with a rabbit polyclonal antiserum to the human cytochrome, P450 2A6 (AFR, BIOMOL International LP, Pennsylvania, USA). The primary antibody (CYP2A6) was applied for $60 \mathrm{~min}$ at room temperature at 100 -fold dilution. Enzyme-labeled biotin-streptavidin techniques were applied throughout with an automated slide staining system using the Ventana HX system Discovery (Ventana Japan, Kanagawa, Japan). In order to determine the CYP2A6 immunoreactivity, cytoplasmic staining was considered to be positive expression. The normal bronchiolar epithelium was positive for CYP2A6 and was therefore used as the internal positive control. At a magnification of $\mathrm{x} 100,10$ randomized microscope images from the lung carcinoma area in each case, were analyzed microscopically. The degree of positive staining for CYP2A6 was evaluated by scoring on a scale of 0-4 for the percentage of positive cells and on a scale of 0-3 for the strength of the staining intensity. The percentage of CYP2A6-positive cells was evaluated using the following scale: 0 , No staining of the mucosal epithelial cells in any field; $1+,<25 \%$ of the epithelium is stained positive; $2+, 25-50 \%$ is stained positive; $3+$, $50-75 \%$ is stained positive; $4+,>75 \%$ is stained positive. As for the evaluation of the strength of intensity of the CYP2A6 staining, this was estimated using the following scale: 0 , No staining of the epithelial cells; $1+$, mild staining; $2+$, moderate staining; and $3+$, intense staining. The total score was generated by adding the score for the percentage of CYP2A6positive cells and the strength of staining intensity. The average value of the results obtained from each of the 10 images was regarded as CYP2A6 indices, and used for statistical analysis.

In situ hybridization (ISH) of CYP2A6. In order to further determine whether CYP2A6 mRNAs are expressed in the same manner as the protein expression, we performed ISH of CYP2A6 in each case of adenocarcinoma and SCC. The cRNA probes for ISH were synthesized as described in previous literature $(17,18)$. Total RNA was extracted from the human liver using the Rneasy mini kit (Qiagen, Hilden, Germany) according to the manufacturer's instructions. cDNA were prepared from total RNA using the TaKaRa RNA PCR Kit (AMV) Ver.3.0 with Random 9mers primers (TaKaRa Bio, Ohtsu, Japan). CYP 2A6 cDNA were amplified by PCR using the 1 st and 2 nd PCR primers, (Table I) added at the nucleotides of the SP6 or T7 promoters. The 1st PCR cycle
Table II. Immunohistochemistry data for CYP2A6 in all the lung carcinoma cases.

\begin{tabular}{lcc}
\hline & $\begin{array}{c}\text { No. of } \\
\text { patients }\end{array}$ & $\begin{array}{c}\text { CYP2A6 } \\
\text { indices }\end{array}$ \\
\hline $\begin{array}{l}\text { Total } \\
\text { Age } 74.10 \pm 1.62\end{array}$ & 31 & $3.58 \pm 0.27$ \\
Gender & & \\
F & 12 & $3.47 \pm 0.40$ \\
M & 19 & $3.66 \pm 0.38$
\end{tabular}

Smoking

Non-smoker

$4.25 \pm 0.48$

Smoker

$2.47 \pm 1.36$

No data

Histology

Adenocarcinoma

Squamous cell carcinoma

Large cell carcinoma

$3.23 \pm 0.47$

Small cell carcinoma

2.00

0.00

Differentiation $^{\mathrm{a}}$

Well

$3.74 \pm 0.37$

Moderate

$3.76 \pm 0.38$

Poor

$3.82 \pm 0.82$

Tumor size

$\leq 30 \mathrm{~mm}$

$3.19 \pm 0.28$

$>30 \mathrm{~mm}$

$3.83 \pm 0.41$

Lymph node metastasis

$$
\text { - }
$$

$3.28 \pm 0.27$

$5.18 \pm 0.67 \mathrm{~b}$

Pleural invasion

$-$

21

$3.53 \pm 0.33$

$+$

10

$3.69 \pm 0.51$

Metastasis in the lung

\begin{tabular}{rrr}
- & 28 & $3.50 \pm 0.29$ \\
+ & 3 & $4.33 \pm 0.78$ \\
\hline
\end{tabular}

${ }^{a}$ The large cell carcinoma and small cell carcinoma cases were excluded; ${ }^{\mathrm{b}} \mathrm{P}<0.01$ vs cases without lymph node metastasis. 


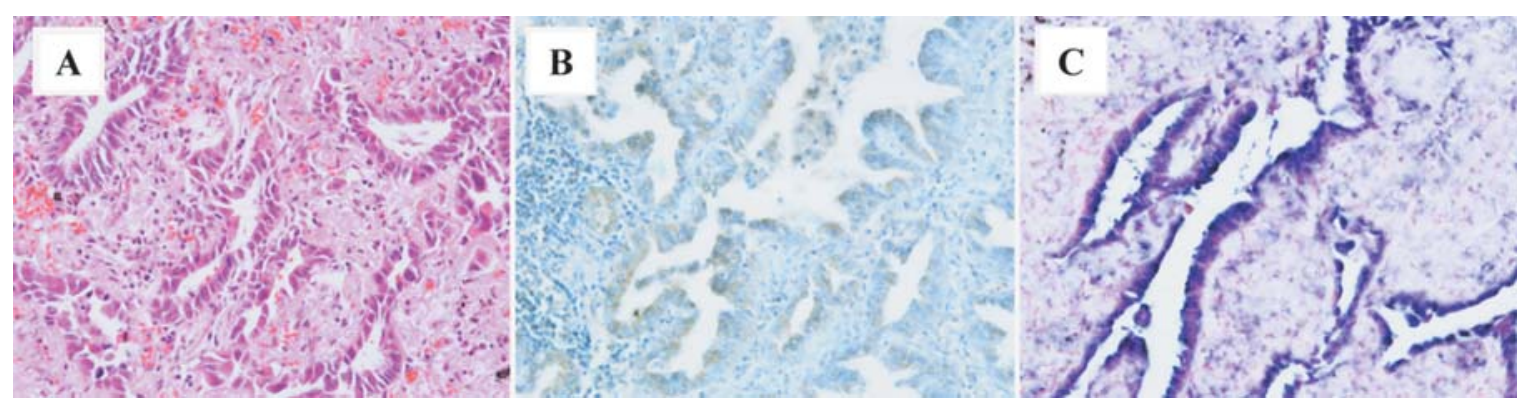

Figure 1. Lung adenocarcinoma case. (A) H\&E staining. (B) Immunohistochemistry for CYP2A6. (C) In situ hybridization for CYP2A6.

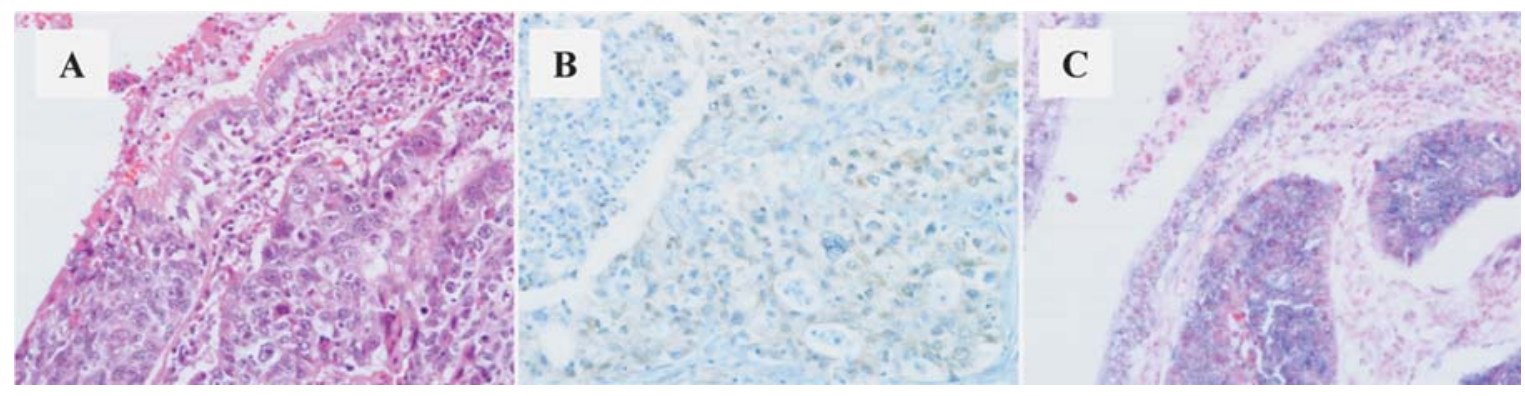

Figure 2. Lung squamous cell carcinoma case. (A) H\&E staining. (B) Immunohistochemistry for CYP2A6. (C) In situ hybridization for CYP2A6.

conditions were at $94^{\circ} \mathrm{C}$ for 2 min followed by 25 cycles at $94^{\circ} \mathrm{C}$ for $30 \mathrm{sec}, 60^{\circ} \mathrm{C}$ for $30 \mathrm{sec}$, and $72^{\circ} \mathrm{C}$ for $1 \mathrm{~min}$. The 2nd PCR cycle conditions were 25 cycles at $94^{\circ} \mathrm{C}$ for $30 \mathrm{sec}$, $62^{\circ} \mathrm{C}$ for $30 \mathrm{sec}$, and $72^{\circ} \mathrm{C}$ for $1 \mathrm{~min}$. After the PCR products were purified using the Pure Link PCR Purification Kit (Invitrogen, Carlsbad, CA, USA), 100 ng PCR products were used for the cRNA sense and antisense probe synthesis. The probes were labeled with digoxigenin (DIG)-uridine triphosphate by SP6 RNA and T7 RNA polymerase using the DIG RNA Labeling Kit (Roche, Penzberg, Germany). Formalinfixed and paraffin-embedded tissues were cut at $6 \mu \mathrm{m}$. ISH was performed by the Ventana HX system Discovery, an automated slide staining system. The sections were hybridized for $6 \mathrm{~h}$ at $66^{\circ} \mathrm{C}$, and the concentration of the cRNA probes was $250 \mathrm{ng} / \mathrm{ml}$.

Statistical analysis. All the quantitative data were presented as the mean \pm SD values, and were assessed using the Student's t-test or post-hoc test. Statistical differences were considered to be significant at the $\mathrm{P}<0.05$ level.

\section{Results}

Immunohistochemistry for CYP2A6 in all lung carcinoma cases. A summary of the results for all 31 cases is shown in Table II. In adenocarcinomas and to a lesser extent in SCCs, carcinoma cells showed cytoplasmic immunoreactivity for CYP2A6 (Figs. 1B and 2B). One case of large cell carcinoma was also positive for CYP2A6 whereas the single small cell carcinoma was negative.

A significantly higher expression of CYP2A6 was apparent in the cases with lymph node metastasis as opposed to those without such evidence of malignancy $(\mathrm{P}<0.01)$. Smokers had lesions with a tendency for low CYP2A6 indices, although this was not statistically significant, possibly due to the limited number of cases. Poor differentiation, large tumor size, and pleural invasion were also associated with a nonsignificant tendency for high CYP2A6 indices. Age and sex exerted no influence.

CYP2A6 immunoreactivity in lung adenocarcinoma cases. A summary of the results for the 23 adenocarcinoma cases is given in Table III. Cases $>30 \mathrm{~mm}$ in tumor size showed significantly higher CYP2A6 indices than their smaller counterparts $(\mathrm{P}<0.01)$.

CYP2A6 immunoreactivity in lung SCC cases. Table IV shows the results for CYP2A6 immunoreactivity in the 6 SCC cases. Differing from the adenocarcinomas, the SCC cases with poor differentiation or large tumor size showed a tendency for low CYP2A6 indices.

ISH for CYP2A6 in lung adenocarcinoma and SCC cases. Figs. $1 \mathrm{C}$ and $2 \mathrm{C}$ illustrate the ISH results. Both the adenocarcinoma and SCC cases showed CYP2A6 mRNA expression in the cytoplasm of carcinoma cells. Normal bronchiolar cells were also positive.

\section{Discussion}

To our knowledge, this is the first report of CYP2A6 expression in human lung cancers identified by immunohistochemistry and ISH, with concordance between the results of the two techniques. It should be noted, that the adenocarcinoma but not the SCC cases with lymph node metastasis or large tumor size showed a significantly high immunoreactivity. It is possible that in the two tumor types, CYP2A6 could have different functions. 
Table III. Immunohistochemistry for CYP2A6 in the adenocarcinoma cases.

$\begin{array}{cc}\text { No. of } & \text { CYP2A6 } \\ \text { patients } & \text { indices }\end{array}$

\section{Total}

$$
\text { Age } 73.13 \pm 1.84
$$$$
23
$$

$3.90 \pm 0.30$

Gender

$\mathrm{F}$

M

\section{9}

14

$3.71 \pm 0.46$

$4.02 \pm 0.40$

Smoking

Non-smoker

Smoker

No data

Differentiation

Well

Moderate

Poor

Invasive status

Brochioalveolar carcinoma

Invasive carcinoma

$\begin{array}{rl}10 & 4.47 \pm 0.47 \\ 1 & 2.70 \\ 12 & \end{array}$

12

6

4

$3.74 \pm 0.37$

$3.87 \pm 0.53$

$4.48 \pm 1.09$

4

$2.90 \pm 0.17$

19

$4.11 \pm 0.34$

Tumor size

$\leq 30 \mathrm{~mm}$

$2.93 \pm 0.27$

$>30 \mathrm{~mm}$

$4.65 \pm 0.38^{\mathrm{a}}$

Lymph node metastasis

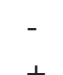

18

$3.54 \pm 0.29$

$+$
Pleural invasion

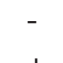

$+$

$3.78 \pm 0.37$

$4.13 \pm 0.54$

Metastasis in the lung

$\begin{array}{rrr}- & 20 & 3.84 \pm 0.33 \\ + & 3 & 4.33 \pm 0.78\end{array}$

${ }^{\mathrm{a}} \mathrm{P}<0.01$ vs cases with $\leq 30 \mathrm{~mm}$ tumor size; ${ }^{\mathrm{b}} \mathrm{P}<0.05$ vs cases without lymph node metastasis.

We hypothesized that the expression of CYP2A6 in lung carcinoma could be associated with smoking behavior, as this is one of the major enzyme forms responsible for the metabolism of tobacco-specific nitrosamines. The reason why smokers were found to have relatively low CYP2A6 indices in their tumors is not clear, but this could be due to the fact that SCCs are more strongly related to tobacco exposure.

An increased CYP2A6 immunoreactivity means an increased expression of the enzyme protein. Recent studies have shown that the genetic polymorphisms of CYP2A6 can also affect enzymatic activity (15). Therefore, future studies could possibly also be focus on CYP2A6 genetic alteration.
Table IV. Immunohistochemistry of CYP2A6 in the squamous cell carcinoma cases.

\begin{tabular}{|c|c|c|}
\hline & $\begin{array}{c}\text { No. of } \\
\text { patients }\end{array}$ & $\begin{array}{c}\text { CYP2A6 } \\
\text { indices }\end{array}$ \\
\hline \multicolumn{3}{|l|}{ Total } \\
\hline Age $78.83 \pm 3.85$ & 6 & $3.23 \pm 0.47$ \\
\hline \multicolumn{3}{|l|}{ Gender } \\
\hline $\mathrm{F}$ & 2 & $3.10 \pm 1.20$ \\
\hline M & 4 & $3.30 \pm 0.56$ \\
\hline \multicolumn{3}{|l|}{ Smoking } \\
\hline Non-smoker & 0 & \\
\hline Smoker & 1 & 4.70 \\
\hline No data & 5 & \\
\hline \multicolumn{3}{|l|}{ Differentiation } \\
\hline Well & 0 & \\
\hline Moderate & 4 & $3.60 \pm 0.60$ \\
\hline Poor & 2 & $2.50 \pm 0.60$ \\
\hline \multicolumn{3}{|l|}{ Tumor size } \\
\hline$\leq 30 \mathrm{~mm}$ & 2 & $4.50 \pm 0.20$ \\
\hline$>30 \mathrm{~mm}$ & 4 & $2.60 \pm 0.38$ \\
\hline \multicolumn{3}{|c|}{ Lymph node metastasis } \\
\hline- & 6 & $3.23 \pm 0.47$ \\
\hline+ & 0 & \\
\hline \multicolumn{3}{|l|}{ Pleural invasion } \\
\hline- & 6 & $3.23 \pm 0.47$ \\
\hline+ & 0 & \\
\hline \multicolumn{3}{|l|}{ Metastasis in the lung } \\
\hline- & 6 & $3.23 \pm 0.47$ \\
\hline+ & 0 & \\
\hline
\end{tabular}

Previously, we reported that the NNK induction of lung adenomas is strongly suppressed by pretreatment with a potent human CYP2A6 inhibitor $(10,11)$. The finding that adenocarcinoma cases with lymph node metastasis or large tumor size showed high levels of CYP2A6 immunoreactivity could thus imply effects on the development of malignancy. Whether CYP2A6 could be a therapeutic candidate and chemopreventive target for lung adenocarcinomas, remains to be confirmed. The mechanisms and role of the CYP2A6 expression have not been clarified, and therefore, more studies with human tissues and human subjects are needed.

\section{References}

1. Parkin DM, Bray F, Ferlay J and Pisani P: Global cancer statistics, 2002. CA Cancer J Clin 55: 74-108, 2005.

2. Hecht SS: Tobacco smoke carcinogens and lung cancer. J Natl Cancer Inst 91: 1194-1210, 1999.

3. Fukami T, Nakajima M, Higashi E, Yamanaka H, Sakai H, McLeod HL and Yokoi T: Characterization of novel CYP2A6 polymorphic alleles (CYP2A6*18 and CYP2A6*19) that affect enzymatic activity. Drug Metab Dispos 33: 1202-1210, 2005. 
4. Kushida H, Fujita K, Suzuki A, Yamada M, Endo T, Nohmi T and Kamataki T: Metabolic activation of $\mathrm{N}$-alkylnitrosamines in genetically engineered Salmonella typhimurium expressing CYP2E1 or CYP2A6 together with human NADPH-cytochrome P450 reductase. Carcinogenesis 21: 1227-1232, 2000.

5. Hughes R, Cross AJ, Pollock JR and Bingham S: Dosedependent effect of dietary meat on endogenous colonic Nnitrosation. Carcinogenesis 22: 199-202, 2001.

6. Ariyoshi N, Miyamoto M, Umetsu Y, Kunitoh H, Dosaka-Akita H, Sawamura Y, Yokota J, Nemoto N, Sato K and Kamataki T: Genetic polymorphism of CYP2A6 gene and tobacco-induced lung cancer risk in male smokers. Cancer Epidemiol Biomarkers Prev 11: 890-894, 2002.

7. Ariyoshi N, Takahashi Y, Miyamoto M, Umetsu Y, Daigo S, Tateishi T, Kobayashi S, Mizorogi Y, Loriot MA, Stucker I, Beaune P, Kinoshita M and Kamataki T: Structural characterization of a new variant of the CYP2A6 gene (CYP2A6*1B) apparently diagnosed as heterozygotes of CYP2A6*1A and CYP2A6*4C. Pharmacogenetics 10: 687-693, 2000.

8. Miyamoto M, Umetsu Y, Dosaka-Akita H, Sawamura Y, Yokota J, Kunitoh H, Nemoto N, Sato K, Ariyoshi N and Kamataki T: CYP2A6 gene deletion reduces susceptibility to lung cancer. Biochem Biophys Res Commun 261: 658-660, 1999.

9. Topcu Z, Chiba I, Fujieda M, Shibata T, Ariyoshi N, Yamazaki H, Sevgican F, Muthumala M, Kobayashi $\mathrm{H}$ and Kamataki T: CYP2A6 gene deletion reduces oral cancer risk in betel quid chewers in Sri Lanka. Carcinogenesis 23: 595-598, 2002.

10. Takeuchi H, Saoo K, Matsuda Y, Yokohira M, Yamakawa K, Zeng Y, Miyazaki M, Fujieda M, Kamataki T and Imaida K: Dose dependent inhibitory effects of dietary 8-methoxypsoralen on NNK-induced lung tumorigenesis in female $\mathrm{A} / \mathrm{J}$ mice. Cancer Lett 234: 232-238, 2005.
11. Takeuchi H, Saoo K, Yokohira M, Ikeda M, Maeta H, Miyazaki M, Yamazaki H, Kamataki T and Imaida K: Pretreatment with 8-methoxypsoralen, a potent human CYP2A6 inhibitor, strongly inhibits lung tumorigenesis induced by 4(methylnitrosamino)-1-(3-pyridyl)-1-butanone in female $\mathrm{A} / \mathrm{J}$ mice. Cancer Res 63: 7581-7583, 2003.

12. Miyazaki M, Yamazaki H, Takeuchi H, Saoo K, Yokohira M, Masumura K, Nohmi T, Funae Y, Imaida K and Kamataki T: Mechanisms of chemopreventive effects of 8-methoxypsoralen against 4-(methylnitrosamino)-1-(3-pyridyl)-1-butanoneinduced mouse lung adenomas. Carcinogenesis 26: 1947-1955, 2005.

13. Crawford EL, Weaver DA, DeMuth JP, Jackson CM, Khuder SA, Frampton MW, Utell MJ, Thilly WG and Willey JC: Measurement of cytochrome P450 2A6 and 2E1 gene expression in primary human bronchial epithelial cells. Carcinogenesis 19: 1867-1871, 1998.

14. Mace K, Bowman ED, Vautravers P, Shields PG, Harris CC and Pfeifer AM: Characterisation of xenobiotic-metabolising enzyme expression in human bronchial mucosa and peripheral lung tissues. Eur J Cancer 34: 914-920, 1998.

15. Travis WD, Brambilla E, Muller-Hermelink HK and Harris CC: Pathology and Genetics of Tumors of the Lung, Pleura, Thymus and Heart. World Health Organization Classification of Tumors. IARCPress, Lyon, 2004.

16. Mountain CF: Revisions in the international system for staging lung cancer. Chest 111: 1710-1717, 1997.

17. Young ID, Ailles L, Deugau K and Kisilevsky R: Transcription of cRNA for in situ hybridization from polymerase chain reaction-amplified DNA. Lab Invest 64: 709-712, 1991.

18. Young ID, Stewart RJ, Ailles L, Mackie A and Gore J: Synthesis of digoxigenin-labeled cRNA probes for nonisotopic in situ hybridization using reverse transcription polymerase chain reaction. Biotech Histochem 68: 153-158, 1993. 